\title{
Further declines of threatened primates in the Korup Project Area, south-west Cameroon
}

\author{
Matthias Waltert, Lien, Koen Faber and Michael Mühlenberg
}

\begin{abstract}
The diurnal primate community of the Korup area of south-west Cameroon is rich in species and high in endemism. Two years monitoring in the Support Zone around Korup National Park have shown that, although all species of the original community are still present, Preuss' red colobus and drill, which were considered to be threatened in the early 1990s, have declined further and are probably facing local extinction. Densities of the crowned monkey also seem to have declined. Only mona and putty-nosed monkeys have an expanded distribution, and densities that are within the range of those reported from previous studies in the region. Although hunting is the most important cause of these declines, logging also appears to be having a detrimental effect. In logged forest group densities of chimpanzee, red-capped mangabey, mona monkey and
\end{abstract}

red-eared monkey decreased between the two survey years, whilst remaining constant or increasing in unlogged forest. The frequency of associations of guenon species did not differ between logged and unlogged study sites, but encounters of associations of all four guenon species were only found in unlogged forest. We strongly recommend enforcement of anti-poaching activities inside the Korup National Park, and establishment of wildlife management in the Support Zone, as only a combined strategy can successfully guarantee the persistence of the wildlife of the region.

Keywords Cameroon, hunting, Korup National Park, participatory wildlife survey, primates, selective logging, West Africa.

\section{Introduction}

South-western Cameroon in West Africa lies within the western sub-region of the Cameroon-Gabon lowland rainforest zone, an area with exceptionally high biodiversity and endemism (Gartlan, 1989; Stuart et al., 1990; Larsen, 1997). The Korup Project, a multilateral conservation effort, lies within this area at the border with Nigeria. Together the Korup National Park, which was created in 1986, and its surrounding Support Zone make up the Korup Project Area (Fig. 1).

Populations of a fifth of all species of African primates occur in the Korup Project Area, eight of which have populations in Korup National Park and the lowlands of the Support Zone (Table 1). These include two Endangered subspecies with restricted ranges: the mainland drill Mandrillus leucophaeus leucophaeus and Preuss' red colobus Procolobus pennantii preussi (Oates, 1996; Hilton-Taylor, 2000). Preuss' red colobus, which has

Matthias Waltert (Corresponding author) and Michael Mühlenberg Centre for Nature Conservation (Dept. I), Georg-August University Göttingen, Von-Siebold-Strasse 2, 37075 Göttingen, Germany. E-mail:mwalter@gwdg.de

Lien and Koen Faber, Korup Project, B.P. 2417 Douala, Cameroon Received 6 September 2001. Revision requested 7 November 2001 Accepted 10 April 2002 been treated as a separate species by some authors (Groves, 1993; Kingdon, 1997), seems to be confined to rainforests in and around the Korup Project Area (Edwards, 1992). Populations of mainland drill also occur outside the Korup Project Area, but unprotected areas within their range are increasingly subject to fragmentation (Gadsby \& Jenkins, 1997), and the Bioko subspecies of drill probably faces extinction (Hearn \& Morra, 2001). The Vulnerable red-eared monkey Cercopithecus erythrotis camerunensis, and the yet unnamed mainland subspecies of the crowned monkey Cercopithecus pogonias occur in Korup and also in the Oban Division of Cross River National Park in south-eastern Nigeria (Oates, 1996; Gautier-Hion et al., 1999). In addition the Endangered subspecies of chimpanzee Pan troglodytes vellerosus of eastern Nigeria and western Cameroon occurs in the Korup region (Oates, 1996).

Studies in the Korup National Park in the early 1990s indicated that densities of the larger mammals were low (Edwards, 1992; Payne, 1992; Powell et al., 1994), and that the high levels of hunting were unsustainable (Infield, 1988). Socio-economic data from the Support Zone of the Korup National Park in the late 1990s indicated a decreasing hunting success (Sanga \& Ndangang, 2000), suggesting a further decline in wildlife populations. Given the economical and social importance of bushmeat (Infield, 1988) and the relatively small size of 


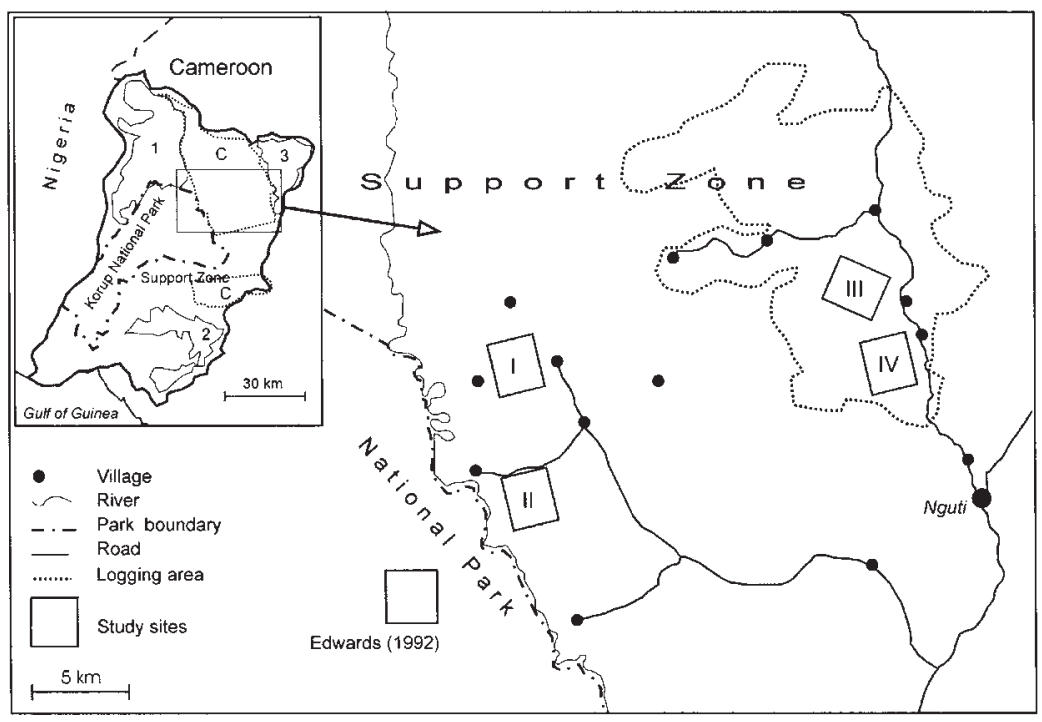

Fig. 1 Location of the Korup Project Area in south-west Cameroon (inset), consisting of the Korup National Park and its surrounding Support Zone (within which $\mathrm{C}$ are logging concessions, and 1, 2 and 3 are Ejagham, Rumpi Hills and Nta Ali Forest Reserves, respectively), and the locations of the four study sites (I and II in unlogged forest and III and IV in logged forest) in the Support Zone, and the site in Korup National Park studied by Edwards (1992) in 1990.

Table 1 Species of diurnal primate found in the study area, their common names, approximate mean weight of adult males, 2000 Red List category and criteria (Hilton-Taylor, 2000), and their range within Africa.

\begin{tabular}{|c|c|c|c|c|}
\hline Species & Common name & $\begin{array}{l}\text { Mean adult male } \\
\text { weight }(\mathrm{kg})^{1}\end{array}$ & $\begin{array}{l}\text { Red List category } \\
(\text { criteria })^{2}\end{array}$ & Range in Africa \\
\hline Procolobus pennantii preussi & Preuss' red colobus & 8.3 & $\mathrm{EN}(\mathrm{B} 1+2 \mathrm{ac})$ & Korup region \\
\hline Cercopithecus mona & mona monkey & 4.5 & - & River Volta to River Sanaga \\
\hline Cercopithecus pogonias subsp. nov. & crowned monkey & 4.5 & - & River Cross to River Sanaga \\
\hline Cercopithecus nictitans ludio & putty-nosed monkey & 6.6 & - & River Cross to River Sanaga \\
\hline Cercopithecus erythrotis camerunensis & red-eared monkey & 4.1 & $\mathrm{VU}(\mathrm{A} 1 \mathrm{~cd}+2 \mathrm{~cd})^{3}$ & River Cross to River Sanaga \\
\hline Cercocebus torquatus & red-capped mangabey & 11.6 & $\mathrm{LR} / \mathrm{nt}$ & W. Nigeria to Gabon \\
\hline Pan troglodytes vellerosus & $\begin{array}{l}\text { E. Nigeria-W. Cameroon } \\
\text { chimpanzee }\end{array}$ & 40.0 & $\mathrm{EN}(\mathrm{A} 1 \mathrm{~cd}+2 \mathrm{~cd})$ & E. Nigeria to W. Cameroon \\
\hline Mandrillus leucophaeus leucophaeus & mainland drill & 40.0 & $\mathrm{EN}(\mathrm{A} 1 \mathrm{acd}+2 \mathrm{~cd})$ & River Cross to River Sanaga \\
\hline
\end{tabular}

${ }^{1}$ From various authors, cited in Edwards (1992).

${ }^{2} \mathrm{EN}=$ Endangered, $\mathrm{VU}=$ Vulnerable, $\mathrm{LR} / \mathrm{nt}=$ Lower Risk: near threatened; criteria refer to quantitative assessment used for categorization (see Hilton-Taylor (2000) for further details).

${ }^{3}$ Refers to species (subspecies not explicitly mentioned in Hilton-Taylor (2000)).

Korup National Park (Fig. 1), decreases in populations of wildlife in the area surrounding the Park are likely to increase hunting pressure within the Park.

The aim of the Korup Project is to combine conservation efforts both within and around Korup National Park. In 1999 we started a community-based survey programme in the Support Zone of the Park to: (1) obtain data on the status and distribution of important species, (2) facilitate long-term documentation of population trends, and (3) investigate the impact of logging on the wildlife. The overall objective is to provide a scientific basis for the development of wildlife management in the Support Zone. Target species are diurnal primates, duikers, large birds (hornbills and turacos), and selected insectivorous birds of the understorey. This paper describes primate densities obtained during two years of regular monitoring in the Korup Support Zone. To examine the conservation status of species we compare our results with population data for primates in the northern part of the National Park in 1990 (Edwards, 1992), and with results of other primate surveys in West and Central Africa (Thomas, 1991; Struhsaker, 1997). We also present results on the impact of logging on primate populations, by comparing data between two logged and two unlogged study sites. In general we find that populations have declined since the early 1990s, with hunting being the primary cause and logging also having a detrimental effect.

\section{Study area}

The Korup Project is a non-profit making nongovernmental organisation assisting the government of Cameroon to implement its biodiversity conservation 
policy. The project is coordinated by the WWF/ Cameroon Programme Office under the directives of the Ministry of Environment and Forests. Staff from this Ministry are attached to the project, as are some from the Ministry of Agriculture, and some staff are also employed directly by the donors, the European Union and the Gesellschaft für Technische Zusammenarbeit, that form the Korup Project. The Korup Project Area (KPA) consists of the Korup National Park $\left(1,253 \mathrm{~km}^{2}\right)$, and the surrounding Support Zone $\left(5,357 \mathrm{~km}^{2}\right)$. The Support Zone contains extensive forests, three forest reserves (Rumpi Hills, Nta Ali, and Ejagham), and two logging concessions $\left(1,396 \mathrm{~km}^{2}\right)$ that were active between 1996 and 1998. There are c. 50,000 people in 182 villages living within KPA, and five of these villages are situated within the National Park. The Korup Project aims to protect the Park's biodiversity and to ensure that the Support Zone's natural resources are used in an ecologically and economically sustainable and socially acceptable manner. Ideally the Support Zone is meant to be managed in a way that minimizes pressure on the Park.

The study area is in the populated part of the Korup Support Zone (Fig. 1). To the east, it borders Nta Ali Forest Reserve, which has no human settlements, and to the west Korup National Park. Clearings for farming are restricted to the immediate surroundings of villages, and although there is some farming alongside the roads, most of the area is still forested. Four sites each of c. $8 \mathrm{~km}^{2}$ were selected for study (Fig. 1). Sites I and II were located in unlogged forest near the boundary of the Park, where the topography is level at an altitude of c. $250 \mathrm{~m}$, and sites III and IV were located to the east in forest logged 2 years previously, where the topography is hilly at altitudes of $200-600 \mathrm{~m}$.

\section{Methods}

The surveys were carried out by four teams, each composed of three field workers experienced in animal tracking and hunting, selected from four villages in the vicinity of the study sites. Most team members were formerly hunters, and are presently employed by the
Korup Project. Between 1997 and 1999 we produced lists of local names of key animal species, and trained the teams in ecological fieldwork and identification skills. Identification of primates was facilitated by colour plates redrawn from Kingdon (1997). Morphological and behavioural descriptions in Kingdon (1997), and recordings of primate calls (Roché, 1994; Bouchain \& Gautier, 1995; Wisconsin Regional Primate Research Centre, http:/ / www.primate.wisc.edu/pin/vocals; Bioko Biodiversity Protection Programme, http://www.bioko.org/sound) were also used.

Data was collected using Distance Sampling, in which measurements of the distances of objects observed from a transect line are used to estimate the probability of observing an object, and thus its density (Buckland et al., 1993; Thomas et al., 2002). Training for accurate distance estimation was carried out, and repeated at regular intervals, with control measurements being made with a laser rangefinder. Each team was supported by an experienced supervisor.

In each of the four study sites we established permanent, straight, 2-km long transects parallel to and c. $200 \mathrm{~m}$ from each other. In the first year of the survey (February 1999-April 2000) two transects were established in each of the unlogged sites and two in logged site III, and these transects were surveyed more-or-less twice monthly. In the second year (May 2000-April 2001) more transects were established, giving a total of 10 in the unlogged and eight in the logged sites, with each being surveyed at 6-week intervals (Table 2). In both years transects were walked between 06.30 and 09.00, at an average speed of $<1 \mathrm{~km} \mathrm{~h}^{-1}$. Estimates were made of the perpendicular distance from the transect to the estimated centre of primate groups, both for visual and acoustic encounters. Group size was estimated only from visual encounters.

Observations were pooled by transect, and survey effort was calculated for each transect as the sum of all distances that were walked without disturbance by rain. Density $(D)$ was calculated as $D=n /\left(2 w L P_{\mathrm{a}}\right)$, where $n=$ number of groups observed, $w=$ transect width, $L=$ transect length and $P_{\mathrm{a}}=$ probability that a randomly chosen group within the survey area $a=2 w L$ is detected. An estimate of $P_{\mathrm{a}}$ was obtained using the Distance

Table 2 Survey effort of primate censuses in two unlogged and two logged forest study sites in the Korup Support Zone (see Fig. 1 for locations). Year 1 was February 1999-April 2000; year 2 was May 2000-April 2001.

\begin{tabular}{lcrrr}
\hline & \multicolumn{2}{c}{ Unlogged (Sites I \& II) } & & Logged (Sites III \& IV) \\
\cline { 2 - 5 } & \multicolumn{1}{c}{ Year 1 } & Year 2 & Year 1 (Site III only) \\
\hline No. of 2 km-long transects & 4 & 10 & 2 & Year 2 \\
Total no. of 2 km surveys & 91 & 90 & 48 & 96 \\
Total km surveyed & 182 & 180 & 138 \\
\hline
\end{tabular}


Sampling software Distance 3.5 (Thomas et al., 1998). We fitted half-normal, hazard rate and uniform models to the data (each model describes a different way in which the probability of sighting an object decreases with distance from the centre line of the transect), and the Akaike Information Criterion (AIC) was used to select models with the least number of parameters and the best fit (Buckland et al., 1993). Data were truncated (i.e. some observations furthest from the centre line were not included) only when this increased the precision of the estimates.

\section{Results}

We used data from both visual and acoustic encounters, because the mean densities of groups thus obtained were similar to that obtained from visual data considered alone, and in combination they gave narrower confidence intervals. Detection probabilities for species for which there were $<20$ observations in each year and study site were generally best described (i.e. had the lowest AIC and the highest precision) by uniform models. For species with adequate sample sizes the half-normal model was used almost exclusively.

Of the eight species of diurnal primate in the Korup Project Area (Table 1) at least four species of guenon (Cercopithecus spp.) and the red-capped mangabey Cercocebus torquatus were recorded in all four study sites (Table 3). The chimpanzee was recorded in only three sites, and the drill and Preuss' red colobus were observed at only two sites. The highest number of species recorded was seven, at site III in logged forest. Abundance patterns were consistent across the four study sites, with the same species being either common or abundant. At most sites the putty-nosed monkey Cercopithecus nictitans and the mona monkey Cercopithecus mona had the highest group densities, followed by the red-eared monkey and the crowned monkey. The redcapped mangabey generally had a lower group density than the guenon species, and group densities of the chimpanzee were within the same range or lower. Because of low encounter rates and/or large differences between transects there were wide $95 \%$ confidence intervals for some of the estimates of encounter rates and density.

During the two years the drill was recorded only twice and Preuss' red colobus only three times. The crowned monkey was the least common guenon in both logged and unlogged forest, detected 13 times. Chimpanzees were observed in low numbers in three sites; estimated group sizes were 6-15 in the logged sites and 12-20 in one unlogged site. Estimates of group size for the red-capped mangabey were 20-33. Density estimates of the red-eared monkey were highly variable between sites. The mona monkey was the second most abundant primate species; estimated median group size was 20 , and the maximum group size seen was 35 . The putty-nosed monkey was the commonest species, with similar densities in both logged and unlogged sites; median group size was 30, with the largest group estimated to be c. 100 individuals.

Figure 2 compares changes in group density between the two study years for the three sites (one logged, two unlogged) for which density estimates were obtained in both years. At the logged site there were negative changes in the density of four species, and small positive changes in the density of two species, whereas at the unlogged sites there was a consistent pattern of little or positive change in densities for all six species.

From a total of 188 visual encounters of primates, 81 records $(43 \%)$ were from mixed groups, and 71 of these $(38 \%)$ were mixed groups of guenon species only (Table 4). There was no significant difference in the proportions of mixed groups between logged and unlogged areas $\left(\chi^{2}=0.005, \mathrm{df}=1, P=0.821\right)$. The most frequently-encountered associations were those between the putty-nosed and the mona monkey, the two commonest species, with the putty-nosed monkey present in $92 \%$ of all associations. Associations of all four species were only found in unlogged areas.

We compared encounter rates in site II with data from a nearby site surveyed in 1990 using similar methodology (Edwards, 1992). The crowned monkey, Preuss' red colobus and drill had lower mean encounters per km in 2000 than in 1990, whereas the mona monkey, puttynosed monkey, red-eared monkey and red-capped mangabey had higher mean encounter rates in 2000 (Table 5).

\section{Discussion}

Of the eight diurnal primate species in the Korup Support Zone five are of conservation concern, and of the four species with restricted ranges we found the

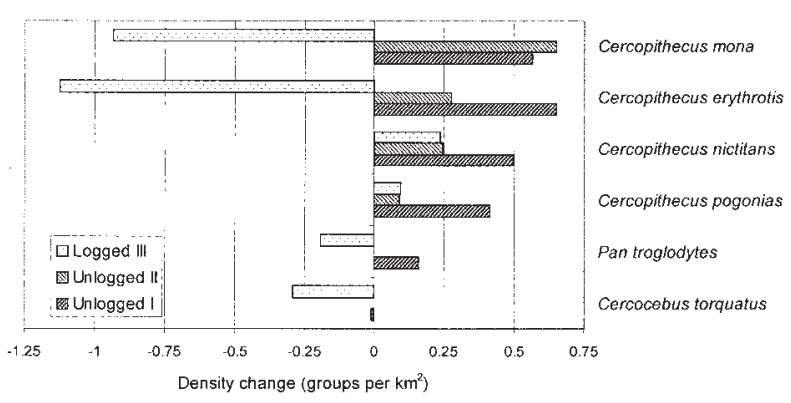

Fig. 2 Density changes in six primate species between 1999 and 2000 in one logged and two unlogged study sites in the Support Zone of Korup National Park. 


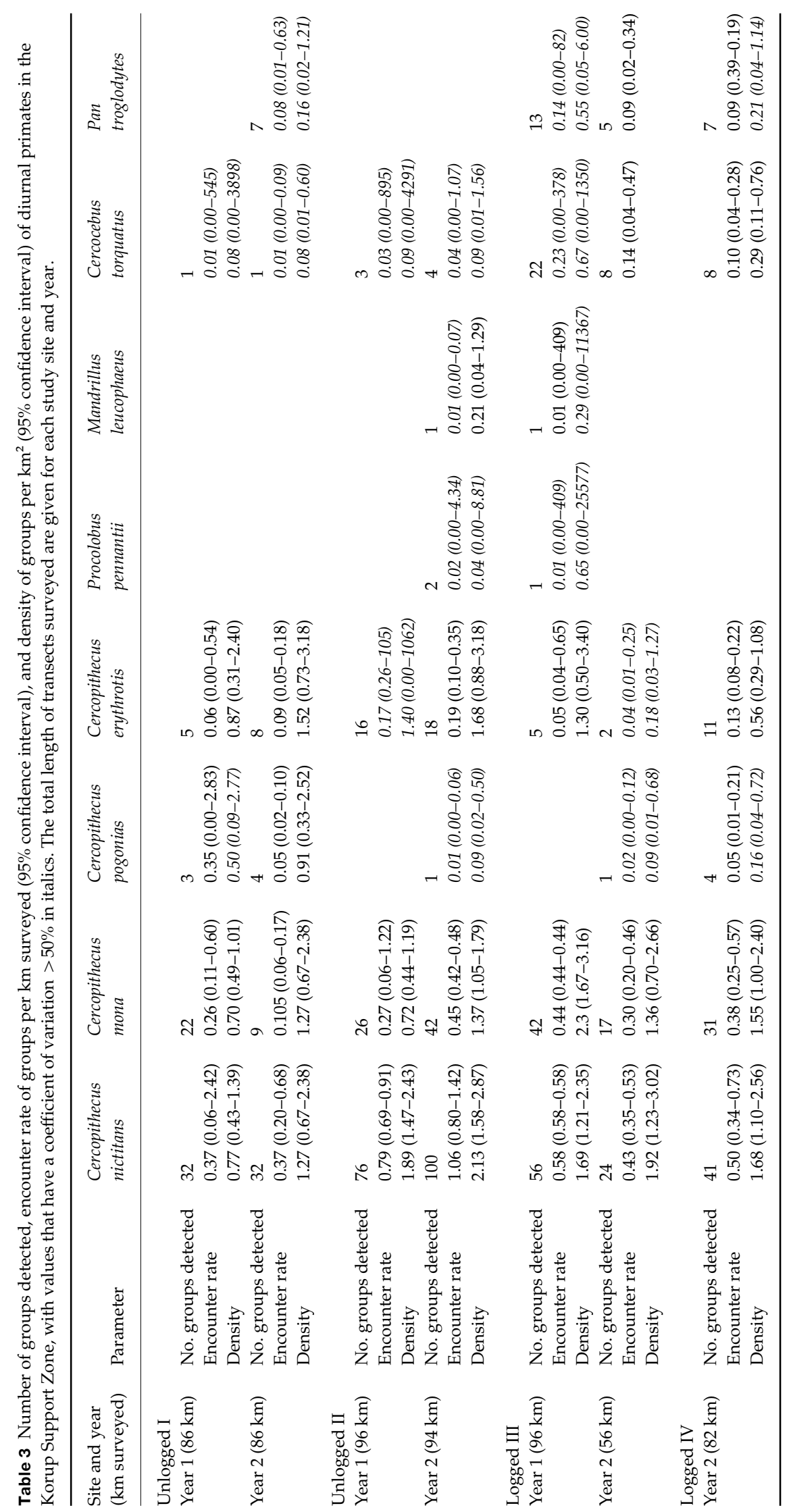

(C) $2002 \mathrm{FFI}$, Oryx, 36(3), 257-265 
Table 4 Frequency (and percentage) of guenon (Cercopithecus spp.) associations in logged and unlogged study sites.

\begin{tabular}{lccr}
\hline & $\begin{array}{l}\text { Logged } \\
\text { sites }^{1}\end{array}$ & $\begin{array}{l}\text { Unlogged } \\
\text { sites }^{2}\end{array}$ & Total \\
\hline $\begin{array}{l}\text { Two species } \\
\text { C. nictitans + C. mona }\end{array}$ & $14(44)$ & $23(47)$ & 37 \\
$\begin{array}{l}\text { C. nictitans + C. erythrotis } \\
\text { C. nictitans + C. pogonias }\end{array}$ & $2(8)$ & $9(18)$ & 11 \\
C. mona + C. erythrotis & $1(3)$ & & 1 \\
Three species & $2(6)$ & $4(8)$ & 6 \\
$\begin{array}{l}\text { C. nictitans + C. erythrotis + C. mona } \\
\text { C. nictitans + C. erythrotis + C. pogonias }\end{array}$ & $4(13)$ & $7(14)$ & 11 \\
Four species & & $1(2)$ & 1 \\
Ceropithecus spp. + Cercocebus & $9(28)$ & $1(2)$ & 4 \\
torquatus, unidentified guenons & & & \\
Total & 32 & 49 & 81 \\
\hline
\end{tabular}

${ }^{1}$ Over a total of $234 \mathrm{~km}$ surveyed.

${ }^{2}$ Over a total of $362 \mathrm{~km}$ surveyed.

Table 5 Numbers of encounters (combined visual and acoustic) and encounter rates of diurnal primate groups/solitary individuals in Korup Project Area. Sample effort was 492 and $94 \mathrm{~km}$ walked in 1990 and 2000, respectively.

\begin{tabular}{lcrrrrrr}
\hline & \multicolumn{2}{c}{ No. encounters } & & \multicolumn{2}{l}{ Encounter rate per km } \\
\cline { 2 - 3 } Species & $1990^{1}$ & $2000^{2}$ & & $1990^{1}$ & $2000^{2}$ & change \\
\hline Procolobus pennantii & 26 & 2 & & 0.05 & 0.02 & -0.03 \\
Cercopithecus mona & 47 & 42 & & 0.10 & 0.45 & +0.35 \\
Cercopithecus pogonias & 42 & 1 & & 0.08 & 0.01 & -0.07 \\
Cercopithecus nictitans & 75 & 100 & & 0.15 & 1.06 & +0.91 \\
Cercopithecus erythrotis & 16 & 18 & & 0.03 & 0.19 & +0.16 \\
Cercocebus torquatus & 2 & 4 & & 0.00 & 0.04 & +0.04 \\
Pan troglodytes & 0 & 0 & & 0.00 & 0.00 & \\
Mandrillus leucophaeus & 8 & 1 & & 0.02 & 0.01 & -0.01 \\
\hline
\end{tabular}

${ }^{1}$ Edwards (1992).

${ }^{2}$ Study site II (this study).

drill Mandrillus leucophaeus leucophaeus and Preuss' red colobus Procolobs pennantii preussi to be rare. The comparison with data from a nearby site in 1990 (Edwards, 1992) suggests that these two species may be declining. In 1990 Edwards (1992) saw drills on four occasions, with an encounter rate of 0.03 groups $\mathrm{km}^{-1}$ and a group density of $0.16 \mathrm{~km}^{-2}$. The low detection of drills during our study suggests that the species has declined further, and reinforces the view of Gadsby and Jenkins (1997) that the global drill population may not be viable. Steiner (2001) located only a single group during $152 \mathrm{~km}$ of reconnaissance walking in April/May 2000 in the Korup National Park and its Support Zone, and interviews with hunters indicated that there has been a recent sharp decline in drill populations, the principal cause being the increased use of hunting dogs (which are used to chase drills up trees, from where whole groups are easily shot).

The situation appears to be similar for Preuss' red colobus. Edwards (1992) had 0.07 visual encounters of groups per $\mathrm{km}$ in 1990, estimated group densities at $0.52-0.56 \mathrm{~km}^{-2}$, and saw group sizes of $20-64$. This density was already low compared to other Procolobus species (Struhsaker, 1975; Thomas, 1991; Whitesides, 1981, in Edwards, 1992), and the considerably lower encounter rates in our study suggest that this species has declined further within the last decade. Hunting is a major threat to these large, mainly folivorous (Usongo \& Amubode, 2000) monkeys, and Struhsaker (1997) reported local extinctions of the species in south-west Cameroon due to hunting. Even as early as 1966 many hunters in the Kumba area of Cameroon did not know the species (Struhsaker, 1997), but in our study area hunters were familiar with the red colobus and reported that $c .30$ years ago large populations were still present within the Support Zone. One form of the Western red colobus, Miss Waldron's red colobus Procolobus badius waldroni, has already become extinct due to logging and hunting (Oates et al., 2000). Red colobus monkeys are also negatively affected by logging. In Kibale, red colobus Procolobus badius tephrosceles seemed to avoid heavily-logged areas (only 1.6-1.97 groups $\mathrm{km}^{-2}$ ), and in moderately-logged areas its densities decreased from 5.2 groups $\mathrm{km}^{-2}$ in $1973-75$ to 3.9 groups $\mathrm{km}^{-2}$ in 1980 (Struhsaker, 1997).

We also encountered the crowned monkey Cercopithecus pogonias at a lower rate than did Edwards (1992) in 1990. Although the species is not presently considered to be threatened our results suggest that in the Korup region, where it occurs sympatrically with the closely related mona monkey C. mona (Oates, 1988; Kingdon, 1997), its status needs to be monitored. We also found that the chimpanzee Pan troglodytes vellerosus, red-capped mangabey Cercocebus torquatus and red-eared monkey Cercopithecus erythrotis camerunensis are at low densities in the study area. Our encounter rate for the chimpanzee Pan troglodytes vellerosus was within the range of that for the species in the Kibale Forest of Uganda (Struhsaker, 1997), where densities were lower, or the species absent, in moderately- or heavily-logged forest compared with unlogged or lightly-logged sites (Struhsaker, 1975; Skorupa, 1988, in Struhsaker, 1997). The redcapped mangabey's principal habitats are mangrove, gallery and swamp forests (Gartlan \& Struhsaker, 1972). As with the chimpanzee, encounter rates and densities dropped between 1999 and 2000 only in the logged study site (Fig. 2).

Edwards (1992) estimated group densities of redeared monkey in the Korup National Park at c. 0.3 
groups $\mathrm{km}^{-2}$, lower than the densities we found in unlogged study sites, but comparable to those in logged study sites. In Kibale Forest densities of the related redtail monkey C. ascanius were variable, and it was negatively influenced by logging (Struhsaker, 1997). The status of the red-eared monkey in Korup warrants close monitoring because, as with the drill and Preuss' red colobus, the Korup/Oban Hills region is its principal conservation area. The nominate subspecies on Bioko island Cercopithecus erythrotis erythrotis is categorized as Endangered (Hilton-Taylor, 2000).

For the two species that were most commonly observed in the study area, densities of the mona monkey appear to have remained stable over the last decade. However, densities of the putty-nosed monkey Cercopithecus nictitans appear to be increasing, comparable to those in the Douala-Edea Forest in Cameroon where three larger, potential competitors (Preuss' red colobus, drill, and red-capped mangabey) were absent (Whitesides, 1981, in Edwards, 1992). Presumed density compensation in primates, due to competitive release following elimination of larger species, has been inferred in Amazonian forests (Peres \& Dolman, 2000). In the KPA C. nictitans is possibly represented by the two subspecies C. nictitans ludio and C. n. nictitans (WWF, 1989; Powell et al., 1994; Oates, 1988). We only found subspecies ludio (formerly martini) in the study area, as did Edwards (1992), but C. n. nictitans could occur at higher elevations.

It is difficult to separate the effects of logging from those of hunting, as hunting pressure usually increases following logging (Struhsaker 1997). We found no evidence of differences in hunting intensity, as measured by number of gunshots heard, between the logged and unlogged sites (unpublished data), and there were no general differences in the primate assemblage between the four study sites. The differences in the density of several primate species between one logged site and the two unlogged study sites over the two years (Fig. 2) could indicate that logging in the Support Zone is having a negative effect. Socio-economic surveys in the northern logged part of the Korup Support Zone indicate decreasing hunting success (Pollard, 1997; Sanga \& Ndangang, 2000).

Multi-species assemblages in vertebrates are a common feature of tropical moist forest and might have evolved because participating members benefit from increased resource use and reduced predation (Diamond, 1981). The numbers of species and individuals taking part in such associations is often negatively influenced by human disturbance. Struhsaker $(1975,1981)$ documented logging effects on associations of primate species, which dropped from $50 \%$ of all contacts in undisturbed forest to $25 \%$ in heavily logged areas. The frequency of associations that we observed was still relatively high (43\%) and comparable to that of $41 \%$ found by Edwards (1992) in 1990. There was also no significant difference in the proportion of mixed groups between the twoyears-old logged site and the unlogged study sites, but associations of all four guenon species were only found in unlogged forest.

Deforestation alone probably makes primate extinction rates in Cameroon and Nigeria the highest in the African forest belt countries (Cowlishaw, 1999), but in the Korup region along the Cameroon-Nigerian border deforestation plays a relatively minor role, as forest cover is still relatively continuous. Hunting and poaching are having the most detrimental effects (Oates, 1999; Hearn \& Morra, 2001), and are the major cause of primate declines. The rarity of the drill and Preuss' red colobus, which were once widespread and common, is confirmed by interviews with hunters in the Support Zone (Steiner, 2001).

Limited information is available on the status of primates within Korup National Park, but preliminary data from a recently instigated monitoring programme indicate that drill and Preuss' red colobus are limited to a narrow strip in the Park's centre (Andrew Dunn, pers. comm.). The Park's relatively small size and rectangular shape (Fig. 1) facilitate access for hunting, and commercial hunting by outsiders may be less easy to prevent inside the Park than in the Support Zone as it is in the villagers interest to keep strangers away from their hunting grounds (Steiner, 2001).

For effective management of primates and other wildlife in this region the conservation of the Korup National Park needs to be linked to the management of wildlife in the Support Zone, and preferably with that of the nearby Oban Hills National Park in Nigeria. A wildlife management plan is also required for the area between the northern Park boundary and the Nta Ali Forest Reserve, where forest cover is probably highest, human population lowest and collaboration between the Korup Project and villages has been most intensive.

Wildlife management in the Korup Support Zone needs to be combined with a long-term environmental education programme such as that which exists in the adjacent Banyang Mbo Sanctuary, run by the Wildlife Conservation Society. Overall aims should be the end of hunting by outsiders in village areas, and respect for the Wildlife Law that already nominally protects many primate species, including drill and chimpanzee. Cooperation of project managers with the Ministry of Environment and Forestry is important, as the forest reserves in the Support Zone are also part of the hunting grounds of the villages. Future projects in the Support Zone could make use of the existing collaboration between Korup Project and its contact persons in the 
villages. These so-called 'village animators' have been encouraged to maintain traditional knowledge for sustainable agriculture and use of non-timber forest products.

The Cameroon Biomonitoring Network (CBN), a young network of existing Cameroonian conservation projects, is seeking to develop into an official platform for the discussion of conservation in the country, but is currently working without resources. Initiatives in fundraising for Korup wildlife management could use the $\mathrm{CBN}$ as a discussion forum, and we recommend that potential donors should liaise with the CBN and acknowledge its establishment.

\section{Acknowledgements}

We thank the Gesellschaft für Technische Zusammenarbeit (GTZ) for initiation and support of wildlife monitoring. Korup Project is a multilateral project sponsored by WWF, the Government of Cameroon, and the European Union. We also acknowledge the work of the Cameroon Biomonitoring Network. We especially thank Karin von Loebenstein, Vincent Ndangang, Andrew Dunn and Albert Kembou. For the fieldwork we thank all survey teams, and the village chiefs of the Korup Project Area who support our programme. For help with the manuscript we thank Heleen Fermon, Christoph Steiner, John F. Oates and two anonymous reviewers.

\section{References}

Bouchain, C. \& Gautier, J.-P. (1995) Primate World 2 - Forest monkeys. Audio-CD, Sittelle, Mens, France.

Buckland, S.T., Anderson, D.R., Burnham, K.P. \& Laake, J.L. (1993) Distance Sampling: Estimating Abundance of Biological Populations. Chapman \& Hall, London, UK.

Cowlishaw, G. (1999) Predicting the pattern of decline of African primate diversity: an extinction debt from historical deforestation. Conservation Biology, 5, 1183-1193.

Diamond, J. (1981) Mixed species foraging groups. Nature, 292, 408-409.

Edwards, A.E. (1992) The diurnal primates of Korup National Park, Cameroon. Abundance, productivity and polyspecific associations. MSc thesis, University of Florida, USA

Gadsby, E.L. \& Jenkins, P.D. (1997) The Drill - Integrated in situ and ex situ conservation. African Primates, 3, 12-18.

Gartlan, S. (1989) La Conservation des Ecosystèmes forestiers $d u$ Cameroun. IUCN, Gland, Switzerland and Cambridge, UK.

Gartlan, J.S. \& Struhsaker, T.T. (1972) Polyspecific associations and niche separation of rain-forest anthropoids in Cameroon, West Africa. Journal of Zoology (London), 168, 221-266.

Gautier-Hion, A., Colyn, M. \& Gautier, J.-P. (1999) Histoire naturelle des Primates d'Afrique Centrale. ECOFAC, Libreville, Gabon.
Groves, C. (1993) Order Primates. In Mammal Species of the World: a Taxonomic and Geographic Reference (eds D.E. Wilson \& D.M. Reeder), pp. 243-277. Smithsonian Institution Press, Washington, DC, USA.

Hearn, G.W. \& Morra, W.A. (2001) The Approaching Extinction of Monkeys and Duikers on Bioko Island, Equatorial Guinea, Africa. Publication no. 7 by the Arcadia University's Bioko Biodiversity Protection Program. Available at http:/ /www.bioko.org

Hilton-Taylor, C. (compiler) (2000) 2000 IUCN Red List of Threatened Species. IUCN, Gland, Switzerland and Cambridge, UK.

Infield, M. (1988) Hunting, Trapping and Fishing in Villages within and at the Periphery of the Korup National Park. WWF Publication no. 3206/A9.6.

Kingdon, J. (1997) The Kingdon Field Guide to African Mammals. Academic Press, London, UK.

Larsen, T.B. (1997) Biodiversity Writ Large. Report to Korup Project, Mundemba, Cameroon.

Oates, J.F. (1988) The distribution and ecology of Cercopithecus monkeys in West African Forests. In A Primate Radiation: Evolutionary Biology of the African Guenons (eds A. Gautier-Hion, F. Bourlière, J.-P. Gautier \& J. Kingdon), pp. 79-103. Cambridge University Press, Cambridge, UK.

Oates, J.F. (1996) African Primates. Status Survey and Conservation Action Plan. Revised edition, IUCN, Gland, Switzerland.

Oates, J.F. (1999) Myth and Reality in the Rain Forest. How Conservation Strategies are Failing in West Africa. University of California Press, Berkeley, USA.

Oates, J.F., Abedi-Lartey, M., McGraw, W.S., Struhsaker, T. \& Whitesides, G. (2000) Extinction of a West African red colobus monkey. Conservation Biology, 14, 1526-1532.

Payne, J.C. (1992) A field study of techniques for estimating densities of duikers in Korup National Park, Cameroon. MSc thesis, University of Florida, USA.

Peres, C.A. \& Dolman, P.M. (2000) Density compensation in neotropical primate communities: evidence from 56 hunted and nonhunted Amazonian forests of varying productivity. Oecologia, 122, 175-189.

Pollard, E.H.B. (1997) Effect of Logging Operations and Economic Decline on Hunting and Trapping in the Northern End of the Korup Project Support Zone. Report to Korup Project, Cameroon

Powell, J.A., Elkan, P., Usongo, L. \& Powell, M.D. (1994) Korup National Park: Report on Research and Conservation Activities of the Cameroon Biodiversity Project. Wildlife Conservation Society. Report prepared for the Biodiversity Support Program and U.S. Agency for International Development, Cameroon Mission, New York.

Roché, J.C. (1994) Primate World 1. Audio-CD. Sittelle, Mens, France.

Sanga, P. \& Ndangang, V. (2000) Development of Participatory Management Plan for Nta Ali Forest Reserve. Unpublished Report, Korup Project, Mundemba, Cameroon.

Steiner, C. (2001) The Drill, an Endangered Species and a Natural Resource in Korup Project Area, Cameroon. Cuvillier, Göttingen, Germany.

Struhsaker, T.T. (1975) The Red Colobus Monkey. University of Chicago Press, Chicago, USA. 
Struhsaker, T.T. (1997) Ecology of an African Rainforest. Logging in Kibale and the Conflict between Conservation and Exploitation. University of Florida Press, Gainesville, Florida, USA

Stuart, S.N., Adams, J.R. \& Jenkins, M.D. (1990) Biodiversity in Sub-Saharan Africa and its Islands: Conservation Management and Sustainable Use. Occasional Papers of the IUCN Species Survival Commission No.6. IUCN, Gland, Switzerland.

Thomas, S.C. (1991) Population densities and patterns of habitat use among anthropoid primates of the Ituri Forest, Zaire. Biotropica, 23, 68-83.

Thomas, L., Buckland, S.T., Burnham, K.P., Anderson, D.R. Laake, J.L., Borchers, D.L. \& Strindberg, S. (2002) Distance Sampling. In Encyclopedia of Environmetrics Volume 1 (eds A.H. El-Shaarawi \& W.W. Piegorsch), pp 544-552. Wiley, Chichester, UK.

Thomas, L., Laake, J.L., Derry, J.F., Buckland, S.T., Borchers, D.L., Anderson, D.R., Burnham, K.P., Strindberg, S., Hedley, S.L., Burt, M.L., Marques, F., Pollard, J.H. \& Fewster, R.M. (1998) Distance 3.5. Research Unit for Wildlife Population Assessment, University of St. Andrews, UK.

Usongo, L.I. \& Amubode, F.O. (2000) Nutritional ecology of Preuss' red colobus monkey (Colobus badius preussi Rahm 1970) in Korup National Park, Cameroon. African Journal of Ecology, 39, 121-125.

WWF (1989) Korup Master Plan. WWF, Yaoundé, Cameroon.

\section{Biographical sketches}

Dr Matthias Waltert is a research scientist at the Centre for Nature Conservation, Göttingen University, Germany. His main interests are community ecology of tropical forest birds and wildlife monitoring. He was responsible for the implementation of the monitoring program in the Korup Support Zone.

Lien is a forest officer with the Conservation Development Component of the Korup Project. His work includes social forestry and the coordination of ecological monitoring in the Korup Support Zone. Lien is one of the founders of the Cameroon Bio-monitoring Network.

Koen Faber graduated in forest ecology from Wageningen University and worked for the German Development Service (DED), which assigned him to the Korup Project. $\mathrm{He}$ is now working for the Netherlands Development Organisation (SNV) in Ecuador.

Prof. Dr Michael Mühlenberg is Director of the Centre for Nature Conservation at Göttingen University, Germany. One of his main interests is wildlife conservation. He initiated and designed the monitoring programme in the Korup Support Zone. 